\title{
Study on User-driven Business Model Innovation for Traditional Manufacturing Enterprises in the "Internet Plus" Age
}

\author{
Xinling $\mathrm{Wu}$ \\ South China Business College \\ Guangdong University of Foreign Studies \\ Guangzhou, China
}

\author{
Yuanyuan Yang \\ South China Business College \\ Guangdong University of Foreign Studies \\ Guangzhou, China
}

\begin{abstract}
In the industrial age, the traditional manufacturing enterprises must pursue the scale, cost and speed. The business model focuses on the enterprise's own value chain and is separate from the market and the users. In the Internet + era, the various market changes brought by the Internet have affected the logic and laws of value creation in manufacturing enterprises. Enterprises need to interact with customers and pursue personalization, user satisfaction, pleasant surprise and loyalty. The user-driven business model is oriented by the individual needs of users, takes the Internet as a basic platform and the big data as the core resources, with the core competence of insight into customers and integrating resources.
\end{abstract}

Keywords-internet; traditional manufacturing enterprise; business model; user-driven

\section{INTRODUCTION}

Traditional manufacturing is an industry that makes manufacturing process to change the resources into the large tools, industrial products and consumer products variable and applicable for people. With the development of the Internet and other technologies, the traditional industrial era is constantly subverted, and human is entering an unprecedented new era and a new business world in which consumers will jointly participate in the business activities. In this era traditional manufacturing enterprises are in a painful situation. Good products may not be popular, which means that the three elements of traditional products, such as "function, quality and price" is out of work, and the small-scale, multi-varieties and flexible product designs determined by individual needs of the customers are more popular; more and more emerging enterprises defeat the traditional enterprises, which means the traditional industrial management logic of "scale determining the benefits" is being subverted. How to better solve the problems of traditional manufacturing enterprises, such as

Fund Project: the fund project (GD14XGL41) is supported by Guangdong Philosophy and Social Science planning: A Study on the Innovation of Business Model of State-owned Enterprises in Guangdong Province--- An Analysis based on the Industrialization of Modern Information Technology. The innovative youth talent program for innovation and consolidation of schools in Guangdong Province (Humanities and Social Sciences) (2016WQNCX202): Study on Innovation and Transformation of Business Model of Manufacturing Industry in "Pearl River Delta" under the Industrialized 4.0 Era. overcapacity, low profit margins, poor product marketability, excessive inventory? In the new era of "Internet +", traditional manufacturing enterprises are required to be capable of making cognition of new environment and changes of business philosophy.

\section{II. "INTERNET Plus" BRINGS ChaLlENGES AND} OPPORTUNITIES FOR MANUFACTURING INDUSTRY

\section{A. The Internet Has Increased the User's Discourse Power, Reshaped the Subject of Value Creation}

In the era without Internet and social media, a large number of information is asymmetric, which makes customers fail in comparing different products and only have passive acceptance of advertising bombardment and terminal sales from manufacturers. In the industrial chain, consumers have no much voice. The Internet is substantially a connection, including the connection of things, the connection of people, the connection of information, and the connection of business and people, and it sets up a practical and quick interactive platform for consumers and enterprises. As a result, it promotes the inversion of discourse power between manufacturers and consumers, making the arrival of the era of consumer sovereignty. Lvben $\mathrm{Fu}$ had talked about the subject of the Internet + : China's Internet + is the result of users' behavior, rather than the result oriented by production, which is a new exploration of consumer behavior rules from the viewpoint of consumers. "Customer first" has become the inexorable law of the Internet era, and customers begin to fully affect the decision-making business of enterprises, which has become a consensus in this era.

The continuous participation of customers greatly impacts the assumptions of the traditional business. The large-scale production, large-scale sales, and the business model from the viewpoint of enterprises have been disintegrated in the Internet age. Therefore, it is the real source of growth for all enterprise to take efforts in the aspect of customers' value. Enterprises can no longer independently take action to design products, develop production flow, elaborate marketing messages and control channels without customers' intervention. The new business logic requires customers increasingly participate in 
the definition of value and the creation of value, achieving a common creation of value by enterprises and users.

\section{B. The Internet Has Enriched the Way of Product Development and Formed a Value Network}

In the industrial age, the product development and design, production and manufacturing, sales and brand operation of traditional manufacturing enterprises are all concentrated in a single enterprise. The operation process of the enterprise is complex and long-term, with great risks, and it is difficult to form and exert the core advantages of the enterprise. In the Internet age, e-commerce and global integration have greatly changed the external environment and technological conditions for the realization of manufacturing value, which has greatly enriched the product design and methods. The open and coordinative, flexible and dynamic, users' creation value oriented thinking and the management concept of the Internet, is permeated into traditional manufacturing sectors, the proportion of the elements used by enterprises for intermediate links and market support has decreased, the trading platforms within and among industries have been further improved, and the business collaboration has been increased. Full data and Internet help enterprises break the barriers of industry, region and business, to achieve the collaboration of the whole industry chains based on the information network, and to build the open industrial ecosystem of complementary advantages and win-win cooperation.

In the industrial era, the supply-oriented scale development is changed into a user-oriented personalized and intelligent design, and each link in production fully embodies the close connection of Internet thinking and user needs.

For example, the Red Collar Group in China has created the $\mathrm{C} 2 \mathrm{M}+\mathrm{O} 2 \mathrm{O}$ business chain of business integration, for which consumers drive manufacturing factories to manufacture and directly sell the products and to create personalized products through digital smart factories. The Haier, Visome, Bosideng, Luthai and other light industrial textiles in China also make use of Internet thinking to achieve a direct dialogue between customers and factories, to form a demand-oriented supply chain cluster, to establish a standardized model base, and to realize personalized custom-scale production mode.

\section{The Internet Has Enriched the Way of Product Marketing and Sales and Opened up the Value Delivery}

The first phase of enterprise Internet is the Internet of communication level, which can make use of Internet tools to achieve brand display, product promotion and other functions; the second phase is the Internet of channel level, which can make use of Internet to achieve product sales.

In the Internet era, the product marketing and sales models of manufacturing enterprises have been greatly enriched. The advent of the Internet has created a flat all-encompassing and truly open environment for users, and the users have become active participants rather than passive recipients. If the 90 s of last century is called "the channel is king", the Internet age is just the era of "customer is king". The "Digital Natives", represented by people who are born in the 1980s, 1990s and 2000s, are leading a completely new consumption model that is mainly characterized by always online, real time, on demand, DIY, and the habit of sharing consumption experience on social media. As a result, the emergence of word-of-mouth marketing and the self-media communication, as well as the shift from PGC to UGC, increasingly reflect the enterprises' comprehension of users' discourse system and psychological needs, as well as the characteristics of information dissemination in the Internet age. On the other hand, with the development of e-commerce, the application of e-commerce platform and $\mathrm{O} 2 \mathrm{O}$ mode (online and offline integration) has expanded the scope and space for sales of manufacturing products, direct sales of e-commerce, precision marketing, and personalized services with user experience as center, have been explored and applied. For example, Yili, Yanghe, Shuanghui and other food manufacturers use WeChat, micro blog, traceability and other ways to position user groups and so as to achieve accurate social marketing and personalized service.

\section{OPERATION REFORM AND COMMERCIAL PATTERN INNOVATION AT THE TIMES OF INTERNET PLUS}

At the times of industry, it was logical that traditional manufacturers were in pursuit of sizes, costs and speeds, which depended on the marketing environment of that time. However, at the times of Internet, key factors to determine whether an enterprise will succeed or not are not what mentioned above but clients' acceptance, satisfaction, surprise and loyalty. Just like what marketing maser Philip Kotler said "To only meet clients' demands is not enough, maybe, more surprises shall be offered", it promoted manufacturers to completely redefine and reconstruct the relations between enterprises and users and more actively seek claims with unique value and highly efficiently engage in the value creation and delivery. Currently manufacturers have to learn how to create value for clients and keep continuous profitability. The market reforms promoted by Internet will ultimately impact on the logic and law for enterprises to create value as shown in "Table I".

TABLE I. THE COMPARISON OF OPERATIONS BETWEEN AT THE TIMES OF TRADITIONAL INDUSTRY AND AT THE TIMES OF INTERNET

\begin{tabular}{|c|c|c|}
\hline Item & Times of Industry & Times of Internet \\
\hline Starting point & Factory & Market \\
\hline Philosophy & Self interest & Altruistic \\
\hline Center & Product & Clients' demand \\
\hline Concept & $\begin{array}{l}\text { Seller's market: Sales } \\
\text { based on production }\end{array}$ & $\begin{array}{l}\text { Buyer's market: Production } \\
\text { based on demands }\end{array}$ \\
\hline $\begin{array}{l}\text { Operating } \\
\text { assumption }\end{array}$ & $\begin{array}{l}\text { Independent } \\
\text { creation }\end{array}$ & $\begin{array}{l}\text { Clients participation in value } \\
\text { determination and creation }\end{array}$ \\
\hline Value creation law & $\begin{array}{l}\text { Large scale, low costs, } \\
\text { speed }\end{array}$ & $\begin{array}{l}\text { Personalized, clients' } \\
\text { satisfaction, surprise, loyalty }\end{array}$ \\
\hline Value realization & $\begin{array}{l}\text { Get resources and attract } \\
\text { clients }\end{array}$ & $\begin{array}{l}\text { Integrate resources and meet } \\
\text { clients }\end{array}$ \\
\hline Dependence & Substantial economy & $\begin{array}{l}\text { Substantial economy+ Internet } \\
\text { platform }\end{array}$ \\
\hline $\begin{array}{l}\text { Organizational } \\
\text { structure }\end{array}$ & Enterprise guided & Client oriented \\
\hline Final & Make profits via sales & $\begin{array}{l}\text { Make profits via satisfying } \\
\text { clients }\end{array}$ \\
\hline
\end{tabular}

User driving: it can be explained from two aspects, first, clients first, clients are basis of all commerce; second, clients rise at the times of Internet, and it is a key for success to 
master the drive of clients' demands. "Table II" indicates comparisons of manufacturing between traditional commercial pattern and user driven pattern at the times of Internet, so as to seek the difference in commerce.

TABLE II. THE COMPARISONS OF MANUFACTURING BETWEEN TRADITIONAL COMMERCIAL PATTERN AND USER DRIVEN PATTERN AT THE TIMES OF INTERNET

\begin{tabular}{|c|c|c|}
\hline Item & $\begin{array}{l}\text { Traditional Commercial } \\
\text { Pattern at the times of } \\
\text { Industry }\end{array}$ & $\begin{array}{c}\text { User-driving Commercial } \\
\text { Pattern at the times of Internet } \\
+\end{array}$ \\
\hline $\begin{array}{l}\text { Value } \\
\text { claims }\end{array}$ & $\begin{array}{l}\text { Clients are only product } \\
\text { buyers; innovation is what } \\
\text { enterprises do inside, which is } \\
\text { highly closed with long } \\
\text { period and high costs; clients } \\
\text { demand for products with } \\
\text { high quality, low costs and } \\
\text { sound performance; clients } \\
\text { buy what enterprises produce. }\end{array}$ & 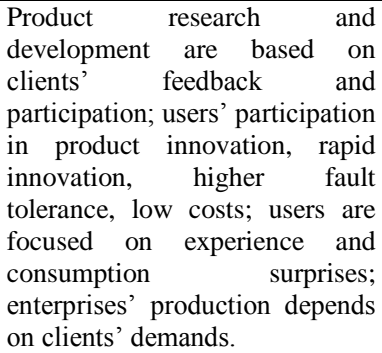 \\
\hline $\begin{array}{l}\text { Value } \\
\text { creati } \\
\text { on }\end{array}$ & $\begin{array}{l}\text { Supply-based development; } \\
\text { based advantages of resources } \\
\text { enterprises own, get external } \\
\text { resources for production; each } \\
\text { process is focused on product } \\
\text { and process quality. }\end{array}$ & $\begin{array}{l}\text { User-orientated personalized and } \\
\text { intellectual production; aim at } \\
\text { clients' demands and integrate } \\
\text { resources for production; each } \\
\text { process is focused on Internet } \\
\text { thought and clients' demands. }\end{array}$ \\
\hline $\begin{array}{l}\text { Value } \\
\text { delive } \\
\text { ry }\end{array}$ & $\begin{array}{l}\text { Traditional media and } \\
\text { marketing; enterprise-guide } \\
\text { marketing (PGC); sales } \\
\text { pattern: one-way purchase, } \\
\text { multiple sales sections, high } \\
\text { costs; channels first. }\end{array}$ & $\begin{array}{l}\text { New media and marketing; } \\
\text { client-oriented market (UGC); } \\
\text { diverse marketing, leading e- } \\
\text { commerce, few sales sections, } \\
\text { low costs; clients first. }\end{array}$ \\
\hline $\begin{array}{l}\text { Value } \\
\text { realiza } \\
\text { tion }\end{array}$ & $\begin{array}{l}\text { Internal costs control to } \\
\text { reduce } \\
\text { consumption; get income via } \\
\text { product sales. }\end{array}$ & $\begin{array}{l}\text { Achieve internal and external } \\
\text { costs reduction via innovation } \\
\text { and clients' participation and } \\
\text { increase resources use } \\
\text { efficiency; get income via } \\
\text { product, service and added } \\
\text { value. }\end{array}$ \\
\hline
\end{tabular}

\section{INNOVATION OF USER DRIVEN COMMERCIAL PATTERN} AT THE TIMES OF INTERNET

At the times of Internet, the innovation of user-driven commercial pattern will aim to meet personalized demands of users, taking Internet as base, big data as core resources, seeing through clients and integrate resources as core capabilities in order to complete the value creation and core logic delivery.

\section{A. User Orientated}

At the times of Internet, the strategy of manufacturing shall be centered on users, all operating activist and organizational design such as R\&D design, production and marketing shall centered on users, and commercial patterns shall be designed on the basis of clients' demand and experience. Users are no only terminal consumers, who are motive power and selective force to drive products and other strategies, as well as participators, interaction doers and influencers, influencing the decisions of enterprises in all aspects.

Enterprises' valve claims and commercial pattern design are conducted from outside to inside, aiming at users. User end is connected with supply chain to form a circle: Users feedback demands to enterprises' R\&D, enterprises purchase materials to generate products or service to be sent to sales end, the sales end contact users to form a second circulation, as such repeated one after another, achieving the dynamic value delivery so as to create value, deliver value and achieve value unceasingly.

\section{B. Internet-based Platform}

Traditional Internet, mobile Internet and upcoming Internet of Things have become vital platforms for enterprise information delivery, establishment of new partnership and client relations as well as business flow optimization, and enterprises' value creation, value delivery and realization are carried out on the basis of Internet.

\section{Big Data as Core Resources}

McKinsey \& Company, which was the first to raise big data concept, thought, data have entered every field of the society, becoming a significant production factor and core driving factor. For manufacturers which are staring at the market trend all the time, the data to be cared are not limited to the business data in the enterprise's database; besides, the data generated by all kinds of online activities shall be valued. Relying on rapid access to data about users, suppliers and those concerned, through process and analysis, manufacturers can break through all levels of internal controls and all sections of value chains via data chains on the basis of Internet, achieve the real time sharing of all data about design, process, manufacturing, supply chain, distribution channels and after sales service and great improve business collaboration and resource allocation optimization so as to better users' demands, seek and form new marketing patterns.

\section{CONCLUSION}

Accompanying with the time of Internet+, a great number of enterprises have combined Internet thought and users' demands and provide and create value for consumers through a different pattern compared to that of traditional enterprises, getting considerable profits and great progress beyond that of traditional patterns. In earlier years, manufacturers almost shared the same patterns, changing little, the coming combination of Internet thought and users' demands prove a brand new space for enterprises' innovation in commercial pattern.

Accordingly targeting the innovation of commercial patters of manufacturers in China, this author raises suggestions as follows: First, actively explore and use Internet thought and achieve the industrial integration and trans-industry operation. With inherent advantages such as operation capitals, resources and experience, traditional enterprises will find it much easier and efficient to upgrade through Internet thought compared to reorganizing traditional enterprises through Internet enterprises. Second, pay close attentions to clients' demands; attract consumers to attend in all aspects. Traditional manufacturers should abandon traditional concepts to produce products only, and borrow the operation and management concepts of service industry and IT industry in order to not only produce high quality products but also offer excellent service and perfect consumption experience, and attract clients to participate 
through new Internet pattern and thought and improve their satisfaction.

\section{REFERENCES}

[1] Chen Chunhua, Sustaining Force of New Business Leaders-Analyze leading gene at the times of traditional industry $[\mathrm{J}]$. Tsinghua Business Review, 2014,04:46-51.

[2] Dong Jielin, Chen Juan, How to reshape the relations between manufactures and users at the times of Internet, based on Study on MI Commercial Pattern Case [J]. China Soft Science, 2015,08:22-33.

[3] Wang Rong, Huang Pei, Ji Jianhua, Transformation and Innovation of Commercial Patterns for Manufacturers [J]. Industrial Engineering and Management, 2002,7(6) : 33-36.

[4] Yang Jirui, Xue Xiao, Wang Rui, Thought of Consumption Transformation under the Background of Internet+ $[\mathrm{J}]$. Consumer Economics, 2015,06:3-7.

[5] Lyu Benfu, What does Internet+ mean? [J] China Information, 2015,05:9-10

[6] Chang Xiaoming, Study on Innovation Trend of Commercial Patterns in Manufacturing [J]. Modern Economic Information, 2014,16:410-411.

[7] Integration of IT and Industrialization Consultancy Service Platform: Report of Enterprise Internet-based Transformation Development (2015) [R]. Published on website of Ministry of Industry and IT of the PRC, Sep 2015.

[8] Wu Guang, Tian Zhiliang, Zhang Youming, Innovation of Commercial Patterns on the Basis of Users' Value [J] Research on The Generalized Fictitious Economy, 2014,03:74-80.

[9] Hao Zhizhong, Users' Force: Demand Driven Products, Operation and Commercial Pattern [M]. China Machine Press, Jan 2016. 